\title{
SCIENCE PLANNING, DEVELOPMENT AND CO-OPERATION IN THE COUNTRIES OF THE MIDDLE EAST AND NORTH AFRICA
}

$\mathrm{A}^{\mathrm{n}}$

REGIONAL conference on the above topie was held under the auspices of Unesco and the United Arab Republic Science Council in the Senate Hall of the House of Representatives, Cairo, during December 19-23. The meeting was organized by the U.N. Science Co-operative Office of the Middle East (director, Mr. Jan Smid) and the United Arab Repub. lic Science Council (secretary-general, Dr. A. F. Ismail). The meeting was attended by delegates from Iraq, Jordan, Lebanon, Morocco, Sudan, Tunisia, Turkey and the United Arab Republic. Three international scientific consultants were in attendance -Prof. J. Coulomb, directeur-général, Centre National de la Recherche Scientifique, Academician M. M. Dubinin, Academy of Science, U.S.S.R., and Prof. M. Stacey, Mason professor and head of the Chemistry Department, University of Birmingham.

The meeting was opened by an address of welcome from the Egyptian Central Minister of Education, His Excellency Kamal El Din Hussein, who discussed the need for co-operation in science and technology at regional and international level, and who emphasized the importance of such a conference for the future development of Middle Eastern and North African countries.

He was followed by Mr. Jan Smid, who spoke of the role of Unesco in the development of scientific research throughout the world. He outlined Unesco's efforts in trying to solve problems of economic planning in the less-advanced countries. He indicated the aims of the Conference as being of particular value in assisting the delegates to set up in thoir own countries some form of permanent centralized national body for co-ordination of scientific research aimed at better economic development of natural resources.

$\mathrm{He}$ emphasized the role of the international consultants. They were present to give their views on science administration based on their experience.

Each of the consultants then gave a short address on science planning and administration within his own country.

After an intermission, Dr. M. A. Haseeb of the Sudan was elected chairman of the conference and the elected vice-chairmen were delegates from Iraq and Turkey. Dr. A. F. Ismail of the United Arab Republic was elected recorder of the meeting. During the following two days delegates gave extensive reports on what was happening in science in their own countries. These may be summarized as follows:

Iraq. Delegates Dr. A. T. Al-Najim, directorgeneral of education, Baghdad; Dr. F. Al Tai, dean of science, University of Beghdad.

The University of Baghdad was prominent in leading scme research activities, and there were two research institutes in the country. Studies in agriculture and forestry were prominent and so were science and medicine. A number of research centres for industry, for example, for petroleum chemistry, were already planned, and schemes were in hand for atomic studies. There was a serious lack of trained scientists and technicians. Much thought was already being given to planning the national effort.
Jordan. Delegates Dr. S. Nashef, director of research, Ministry of Agriculture; Mr. A. Fouzi, under-secretery, Ministry of Public Works.

Jordan had no university, but there was a growing awareness of the importance of scientific research for the future development of the country. Various ministries had undertaken important research projects, for example, in agriculture, health, public works, etc. The Jordan Development Board, through its planning committee, was undertaking much research. Many industrial firms such as the Potash Co. were applying results of research. Many students were being trained abroad.

The country was beset with many difficulties. There was an urgent need for a central body for co-ordinating and financing research. There was a serious lack of scientists and trained technicians and a need for raising the status and salaries of those they had at present.

Lebanon. Delegates Mr. Joseph Naggar, president of the Central Scientific Commission for Lebanon; Dr. M. Attie, director, Industrial Research Institute.

There were three universities in Lebanon: (1) The Lebanon University, a recent foundation with quite well-equipped laboratories for research, especially in chemistry, physics and biology. (2) The American University with well-equipped science laboratories and with attached Schools of Engineer. ing, Medicine, Agriculture and Economics. (3) The University of St. Joseph-a French University with good departments, but now lacking in funds.

There are a number of research institutes and also two good observatories. Scientific research in Lebanon lacks co-ordination, and urgently needs planning at the national level.

Morocco. Delegate Dr. Abdel L. Bennis, director, Agronomical Research Centre of Rabat.

There are a number of scientific research institutes in Morocco, for example, the Laboratory of Chemistry and Physics with divisions of hydrology, biological chemistry, hygiene, etc. 'There are also Laboratories of Parasitology, Entomology, Microbiology and General Biology. There are Departments of Botany, Chemistry, Geology (with an Institute of Geology) in what is termed the Faculty of Science of Moroceo. An Agricultural Research Institute is under the care of the Ministry of Agriculture. There is a scientific institute, L'Institut Scientific Cherifeon, which was founded in 1921 with the object of co-ordinating science, and it has done valuable work in many disciplines and has given help with founding libraries, museums, etc.

There is a great need for a central science council for which the Government has now given approval. There was a grave shortage of scientists and technicians.

Sudan. Delegates Dr. M. Ali Haseeb, assistant director of research, Ministry of Health; Mr. A. A. El Karib, assistant director, Ministry of Animal Resources.

This country has 11 million people spread out over a million square miles. Its climate varies from desert 
to tropical and subtropical and it has rich natural resources of minerals and agricultural products. Cotton is the main export.

The University of Khartoum is well established, and is very active in many faculties such as Science, Agriculture, Engineering, Veterinary, Arts and Law. A good deal of research is applied for national needs. There are many institutes of the various ministries which carry out research, for example, Agriculture, Irrigation, Animal Resources, Tropical Medicine. The Government is sympathetic to potential developments through science. Many more scientists and technicians are needed in the country.

Tunisia. Delegatos Mr. Hamza, head of the Fraculty of Sciences, director of research on arid zone problems, University of Tunis; Mr. Talbi, professor, Faculty of Letters and Science, University of Tunis.

The country has some traditions in science, for the Pasteur Institute of Tunis was created many years ago. Researches in the natural sciences, etc., have been carried out in institutes under various ministries, for example, of Education and Agriculture. Connexions with France have been close, and results of researches have been published in French scientific journals. Now a University of Tunis has been created (March 1960) which, although needing 10 years to build, will cater for 15,000 students and will have powerful science faculties and research facilities. The general outlook for science collaboration in Tunisia is promising.

Turkey. Delegates Prof. H. N. Pamir, Univercity of Istanbul ; Prof. N. Serdaroglu, Technical University, Istanbul.

Scientific research is carried out in the Universities, in laboratories attached to ministries and at a few special institutes. There are six UniversitiesIstanbul, Ankara, d'Ego, Ataturk, the Technical University at Ankara and the Technical University of Istanbul. Between them most scientific disciplines are taught, and research facilities are good. Most specialists' subjects such as agriculture are studied in the Ministry Laboratories, of which there are eight. The special research institutes are medical, for example, for tuberculosis and cancer. Much thought is being given at present to the formation of a council for science, but many difficulties must be overcome.

United Arab Republic. Delegates Dr. A. R. Tourkey, director, National Research Centre, Cairo; Dr. M. M. Ahmed, vice-rector, University of Cairo; Dr. A. F. Ismail and Dr. M. K. Tolba, Science Council ; and Dr. M. B. Ahmed, University of Cairo ; Dr. Y. Khouri and Dr. S. Al Safadi, University of Damascus.

Comparatively speaking, the United Arab Republic is very well organized, and the powerful Science Council which co-ordinates science in Egypt and Syria has just published its third annual report together with a report to Unesco. Both of these make impressive reading. The five UniversitiesCairo, Ain Shams (Cairo), Alexandria, Assiout and Damascus-are all being considerably expanded, especially on the research side. The building of the large science centre in Cairo is well advanced, and there are many other research institutes, for example, for atomic research.

The projects being attempted are largely aimed at developing natural resources and are making good progress. The United Arab Republic is already playing the part of a centre of scientific training for the region. Its own problems, however, are still very great : especially a need for more high-quality scientists to act as research leaders, for skilled technicians, for better information and library facilities, for expensive apparatus, etc.

In the lively discussions which followed, many important and not unfamiliar points emerged. It was clear that there is already a good foundation in most countries on which sound national and regional developments in science can be built. There is urgent need for firm and substantial govermment support, for fair treatment of scientists and for good co-operation through Uneseo.

Finally, it was possible for the conference to pass the following Resolutions :

(1) That a central science council or a similar body should be established in each Member State with the aim of organizing, reinforcing and co-ordinating pure and applied scientific research as well as promoting research projects leading to the economic, social and intellectual development of the nation.

(2) That this council or body has public utility status and financial autonomy, and is directly attached to the office of the Prime Minister, having a limited membership including representatives of universities, interested ministries and scientific institutions as well as certain scientists and experts in industry and agriculture.

(3) That the Member States allocate to this council a sufficient budget which would enable it to accomplish its mission, and that total expenses for scientific research in the country are progressively increased in order to attain not less than 1 per cent of national income.

(4) That this central body should first make use of the existing research institutions by improving their possibilities and promote establishment of new laboratories in fields essential to national needs.

(5) That this council establishes the priority of various projects of applied research of national importance after preliminary study made by special committees formed by the council.

(6) That the council executes the adopted research projects either in its own laboratories or in co-operation with other competent scientific institutions.

(7) That a national scientific documentation centre be established in each Member State, with the aid of Unesco if necessary and on request, which will be attached to the council and charged with providing scientists with the necessary scientific information.

(8) That the Member States undertake adequate training of scientists necessary to the country by strengthening faculties, universities and institutions, and by establishing new ones as well as missions abroad.

(9) That the Member States define and establish the appropriate status of scientific workers together with provision of the material conditions corresponding to the highest scale existing in the country.

(10) That the Member States give attention to the training and improvement of material and moral conditions of auxiliary and technical personnel of laboratories.

(11) That the public and private resources grant housing and financial assistance to universities and institutions of scientific research to enable them to undertake the execution of their projects as is done at present in other countries.

It is recommended to the Member States that such grants are exempted from all taxes. 
(12) That the council has a duty to promote regional and international co-operation, to elaborate the scientific parts of bilateral and international cultural agreements and to represent the country in international scientific non-governmental organizations.

(13) That the Member States grant sufficient means for the exchange of their professors and scientific workers and request Unesco to anticipate in its budget for 1963-64 a supplementary provision to accomplish this aim.

(14) That the Member States promote organization of national or regional scientific congresses and symposia as well as participation in international meetings.

(15) That the Member States support their scientific institutions in co-operation with similar establish- ments in other countries to solve problems of regional or international importance.

(16) That Unesco should continue to promote the organization of symposia and regional scientific meetings to discuss subjects of interest to various Member States.

(17) That all efforts and results reached by science should be used solely to help humanity and to improve the standard of living of the peoples.

(18) The conference thanks the Middle East Science Co-operation Office of Unesco, the Science Council of the United Arab Republic as well as the international consultants, and recommends that Unesco should organize within two years a similar conference to study the progress made in the field of scientific research in the Member States.

\section{ELECTRICAL ENGINEERING IN THE ROYAL NAVY}

$\mathrm{A}^{\mathrm{T}}$ T almost the same time as he relinquished, by retirement, the post of director of electrical engineering at the Admiralty, Sir Hamish Maclaren assumed office as president of the Institution of Electrical Engineers. This is only the second occasion on which the chief electrical engineer of the Admiralty has occupied the presidential chair of the Institution. C. H. Wordingham, who became head of the Electrical Engineering Department of the Admiralty in 1903, was president of the Institution during 1916-18.

Very appropriately, in his presidential address delivered on October 6, Sir Hamish reviewed the development of electrical engineering in the Royal Navy. The electronic equipment and control gear of the submarine utilizing nuclear propulsion plant represents the culmination of some ninety years of development of the applications of electricity in naval vessels, the first being the electrical firing of guns. It was, however, nearly twenty years earlier that the Admiralty made its earliest uses of electrical signalling when in 1852 the twenty-two semaphore stations between Plymouth and Whitehall were replaced by an electric telegraph.

The first dynamo was installed in a warship in 1875 to provide power for a searchlight to be used against torpedo craft, and it is probably this early association with torpedoes that established the practice of placing the responsibility for all electrical equipment in ships on the torpedo officer. This practice remained in force until 1946 when the electrical branch was founded.

A combined ship lighting and searchlight installation was fitted in H.M.S. Inflexible in 1881, Swan incandescent lamps being connected in groups in series. By 1886 first-class ships were being equipped with three dynamos each supplying 200 amp. at $80 \mathrm{~V}$.

The ring-main system of distribution at $22-\mathrm{V}$. direct current was introduced in the early years of the present century and remained the standard naval practice until after the end of the Second World War.

It was in 1896 that the remarkable pioneering experiments in wireless telegraph communication between ships were made by Captain H. B. Jackson. Communication was established between H.M.S.'s Defiance and Scourge over a range of 5,800 yards. In 1899 Marconi equipment with a range of up to seventy miles was installed in four ships.
Experience during action in the First World War focused attention on the impracticability of maintaining so-called watertight enclosures watertight, and means were devised for isolating, automatically, flooded equipment from the supply.

After the War the Admiralty reviewed the experience, to date, of electricity supply in warships and in particular considered the possible introduction of alternating current. Considerable importance, perhaps an undue amount, was attached to the ease and convenience of speed variation of the direct current motor and direct current was retained.

The application of electricity in fire control systems was greatly advanced during the First World War. Individual components such as plotting tables, data transmission and communication instruments had, however, been developed largely by individual specialist firms, giving rise to diversity of design and practice.

It was towards the end of the First World War that the gun director system was introduced in which a gyroscope was employed as a stable reference to ensure that the guns fired only when the ship was in a horizontal position during rolling. This was a prelude to the day when directors and gun mountings would themselves be stabilized.

Between the two World Wars action was taken towards achieving uniformity of practice in instrumentation. Much effort was directed towards the design of fire control computers, and, as the importance of air attack increased, to the special problems associated with the control of high-angle anti-aircraft guns. Of the work done at the Admiralty Research Laboratory during that period mention should be made of the plotting table which automatically records the ship's position on a chart, of the 'magslip', a data-transmission unit of much greater accuracy than any other available at that time, and of an electrically controlled oil-operated remote-power system for searchlights.

The outbreak of the Second World War produced immediately the problem of combating the novel and ingenious devices which had been developed by the enemy. The first was the magnetic mine. Real success in sweeping the magnetic mine was achieved with the development of the towed buoyant-cable sweep whereby a relatively large magnetic field is produced in the sea by circulating current pulses of 